\title{
一戸建て住宅戸外空間の囲繞形態とプライバシー感に関する研究1) RESEARCH ON ENCLOSURE FORM AND A FEELING OF PRIVACY OF THE DETACHED HOUSING OUTDOOR SPACE
}

\author{
竹嶋 祥夫*, 住友 むつみ** \\ Yoshio TAKESHIMA and Mutsumi SUMITOMO
}

\begin{abstract}
Recently, it can be feeled that residential section landscape is more opened visually .
The purpose of this research is to analyze the enclosure form of the detached housing outdoor space, especially (1) present states of enclosure form, (2) whether these enclosure form are affirmative or not, (3) a feeling of privacy according to the stage of openness.

Investigation is being done with a questionnaire method for the housing more than $200 \mathrm{~m}^{2}$ in area. The main contents of investigation are the Real and Ideal conditions of ground height, description and height of enclosure, a feeling of privacy at the garden and inside of the house .
\end{abstract}

Keywords : garden, enclosure form, feeling of privacy

庭、囲繞形態、プライバシー感

\section{1 はじめに}

住宅地、特に郊外の住宅地において一戸建て住宅を計画する場合、 「居間は南面に大きく開口して計画し、その前面に主庭をおき、居間から の景観確保之同時に居間からの生活行為の展開や連続性を計る」という のが一般的であった。この考えには、内部空間としての居間、その延長と しての庭、つまり居間にプライバシーが必要ならばその延長としての庭に もプライバシーが必要との視点があり、そのために主庭の確保と同時に 外部からの視線の遮断(すなわち、居間や庭のプライバシー確保)のた め、いろいろな計画が提案・寒施されてきたし、その手法が教示されてき $た^{2)}$ 。

しかし、近年の住宅地景観を見ると、和風庭園が減少すると共に、複 数台駐車スペースの確保、ガーデニングブームなど、多様な使い方がさ れ、まとまった庭面積が堿少すると同時に様々な形式の庭が造られるよう になっている。また、それらを高い塀で視覚的に囲い込むことも少なくな り、その結果、住宅開口部や庭のプライバシーが確保されず、外部から の視線に曝されることが多くなったと感じられる。

本研究はこのような現状に対して、(1)宅地囲繞の現状を把握し、(2)居 住者はこのような囲繞形態の現状を肯定的に捉えているのだろうか、本 当はどのようにしたいと考えているのか、を把握すると共に、(3)庭や家の
中に対する視線に依る侵害、すなわち見え方によるプライバシー侵害を どのように感じているのか、を考察しようとするものである。

既往の研究: 地方都市において庭のデザインやその変容 (空間構成

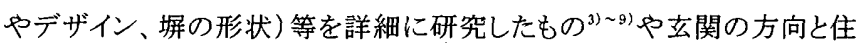
居形状 ${ }^{10)}$ 、住居の配置などを研究したもの ${ }^{11}$ などがある。また、塀の高さ を敷地内外から計測すると共に、塀に対する期待を分析したもの ${ }^{12)}$ があ り、それぞれ有益な結果を示している。しかし、本研究は、上記各研究と 類似の点はあるものの、敷地規模的にも類似し、かつ標準的な広さの比 較的新しい住宅地を対象としていること、住宅敷地外からの視線や居住 者のプライバシー感を中心課題としていることなどにより、標淮的住宅地 にお汁る近年の考え方を把握できることに特徵があると考えている。

\section{2 研究の方法}

\section{2-1 調查対象地とその選定}

本研究のような調查を行う場合、狭い宅地ではプライバシー確保以前 の問題があり、ある程度以上の敷地規模が必要であることと、比較的新し い住宅地であることが要件になる。そのため、最低宅地規模が明確に規 定されており $\left(200 \mathrm{~m}^{2} 、 60\right.$ 坪)，なおかつ建設年度が比較的新しい大阪 都市圏近郊の郊外住宅地である「大和真美ヶ丘ニュータウン」(奈良県
本詥文は，参教文献1)に加筆・修正を加之たものである。

* 大阪産業大学工学部環境デザイン学科 教授・工博

** 大阪産業大学大学院環境デザイン尃攻 大学院生
Prof., Dept. of Environmental Design, Faculty of Engineering, Osaka Sangyo Univ., Dr. Eng.

Graduate Student, Dept. of Environmental Design, Faculty of Engineering, Osaka Sangyo Univ. 
香芝市・広陵町)を対象地域とする。

大和真美ヶ丘ニュータウンは、日本住宅公団 (当時)による「真美ヶ丘 土地区画整理事業」よる新規開発地で、昭和 41 年 12 月に都市計画決定 され、昭和58年4月より入居開始されている(面楀297.8ha、計画人口4万 人)。土地区画整理事業のため、住宅建設の時期はバラバラで、現在で も未利用宅地が残っているが、本研究では、その中でも比較的最近に地 域全体として住宅が充足しつつある区域を対象とする(馬見北2〜3丁 目、馬見北5 7丁目)。

2-2 調查の方法と日時

調查は質問紙法で、直接配布し、後日直接回収している。具体的に は、対象地域の全住戸を訪問し(739戸)、調查協力が得られた住戸(34 0 戸)を対象に配布・回収を行っている。回収数は 278 戸(回収率 $81.8 \%$ ) である゙ いて家族で相談は可）としている。

調查期間については、配布は平成 14 年 10 月 2 日〜 7日、回収は平成 1 4 年10月11日〜 17の各3日間である。

\section{2-3 調査の概要}

主たる調查内容は、宅地囲繞形態の現状と理想、家や庭に対するプ ライバシー感、回答者の属性等である。

\section{3 結果と考察}

3-1 回答者の諸特性

敷地規模は200〜 $250 \mathrm{~m}^{2}$ で $86.5 \% 、 300 \mathrm{~m}^{2}$ 以下で小計 $94.1 \%$ 、中央 値は $220 \mathrm{~m}^{2}$ とかなり似通った規模といえる（不明41戸除く）。建設 年度（図 1) は平成 5 年以降が約 $52 \%$ で比較的新しい家が多い。回 答者（表 1) は、女性が多く、20代以外は各年齢層で似通った数で あるが、男女年齢層で差異があり、女性は30〜 50代、男性は60代が 多い。

\section{3-2 敨地方位の現状と理想}

日照を考慮し、南面方向に居間など主要な居室や庭を設けることが多 い我が国においては、敷地のどちら側に道路があるかによって、敷地計 画を含めた全体的な計画が異なり、かつ外部からの見え方も異なること が予想される。そこで、現在の敷地の方位ならびに理想とする方位を聞 いたのが表2である。

本対象地域は東西方向の道路網が多いため、敷地の方位は南が最も 多く(84戸、31.9\%)、次いで北(73戸、27.8\%)で、他はおおむね似通つ た值を示している(14〜25戸)。

理想とする䇅地方位は、現状と強い関連性があるが、いずれの場合も 南東角地が好まれており、63.9\%を占める。次いで、おおむね現状と同 じ方位が多い。自由回答による選択理由では、南東角地は現状方位に かかわらず「日当たりがよい」角地（または、朝日が差す、隣家が片方の

み)」という理由が大半である。南面も同様で「日当たりがよい」という理由 が多いが、角地を嫌う回答もある(現状南面の内、4件)。なお、特徴的な のは現状一理想とも北面で、「南側のプライバシーが守られる」や「自由 に庭作りが出来る」といら回答が 15 件中 12 件見られることである。

なお、本調查地域の一区画における住宅・都市整備公団 (当時)の宅 地売り出し価格 (平成10年11月) は南東角が最も高く、次いで南西角 > 南 $>$ 北東角 $>$ 北西角 $>$ 北で、必ずしも理想の方位とは合致しない面が 見られる。

3-3 敷地囲繞形態の現状と理想

3-3-1 地盤高さの現状と理想

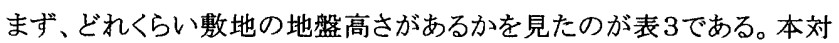
象ニュータウンは、小高い丘陵地が続く地形のため、地域全体に道路面 より地盤面の高い敷地が多く見られ、本調查地域でも約 $1 \mathrm{~m}$ が $34.1 \%$ と 最も多いが、約 $1.5 \mathrm{~m}$ 以上の地盤も合計 $47.6 \%$ と半数近くになる。

理想とする地盤高さは全体的に約 $1 \mathrm{~m}$ が最も多く、次いで約 $50 \mathrm{~cm}$ とな る。理想とする高さは、現状と同じ高さを選ぶことが多いが、次位としては 約 $1.5 \mathrm{~m}$ 以上の高さでは約 $1 \mathrm{~m} \sim 50 \mathrm{~cm}$ 低く、約 $1 \mathrm{~m}$ では $50 \mathrm{~cm}$ 低く選ばれる ことが多い。道路面と同じ高さや約 $2 \mathrm{~m}$ 以上の高さはそれぞれ $13.1 \% 、 1$ $1.2 \%$ でそれほど高い選択率ではない。

\section{3-3-2 敷地囲繞の現状と理想}

\section{（1）塀の有無}

塀は道路側・隣家側・裏家側いずれも有りが最も多いが、道路側よりも 隣家側や裏家側が多い。なお、戸別に見ると四周す心゙て有りが $78.2 \%$ で、次いで道路面以外すべて有りが $13.0 \%$ とるが、すべてなしは非常 に少なく3例のみである。

\section{（2）塀の高さ}

\section{1) 道路側}

塀の高さ(表4) は、道路側は「目線高さ以上」が最も多く約 $66.7 \%$ 、次 いで「目線高さ」で、両者併せて $87.1 \%$ になり、一応乗り越えることが困難 な高さが確保されている。しかし、この高さは地盤の高さを加えた高さで あり、家屋の側から見た高さ (道路側家面と略称)とは異なる。道路側家 面は、「腰の高さ」が最も多く $44.7 \%$ 、次いで「目線高さ」であり、道路側よ りは一段と低く、閉鎖感は緩和されている。

では、居住者はこの高さをどのように考えているのだろうか。道路側か ら見た理想の塀の高さは「目線高さ以上」が最も多く $45.1 \%$ 、次いで「目 線高さ」で、現状と同じ順位であるが值的には「目線高さ以上」が減少し、

表1 回答者の年齢

\begin{tabular}{|c|c|c|c|c|c|c|} 
表1 & 回答者の年齢 \\
\hline & 20 代 & 30 代 & 40 代 & 50 代 & 60 代 & 計 \\
\hline 男 & 2 & 6 & 13 & 20 & 29 & 70 \\
\hline 女 & 5 & 52 & 47 & 48 & 25 & 177 \\
\hline 計 & 7 & 58 & 60 & 68 & 54 & 247 \\
\hline
\end{tabular}

表2 敷地方位の現状と理想

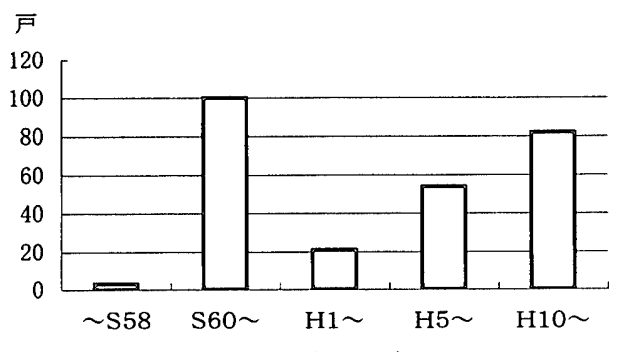

図1 建設年度

\begin{tabular}{|c|c|c|c|c|c|c|c|c|c|c|}
\hline & \multicolumn{9}{|c|}{ 理 } \\
\hline & & 北西角 & 北 & 北東角 & 東 & 南東角 & 南 & 南西角 & 西 & 合計 \\
\hline \multirow{5}{*}{ 現 } & 北西角 & $5(35.7)$ & 0 & $1(7.1)$ & 0 & $7(50.0)$ & $1(7.1)$ & 0 & 0 & $14(100)$ \\
\hline & 北 & 0 & $16(21.9)$ & $6(8.2)$ & 0 & $34(46.6)$ & $12(16.4)$ & $4(5.5)$ & $1(1.4)$ & $73(100)$ \\
\hline & 北東角 & 0 & 0 & 0 & $1(6.7)$ & $12(80.0)$ & 0 & $2(13.3)$ & 0 & $15(100)$ \\
\hline & 東 & 0 & 0 & $1(6.7)$ & $.2(13.3)$ & $10(66.7)$ & $2(13.3)$ & 0 & 0 & $15(100)$ \\
\hline & 南東角 & 0 & 0 & $1(6.3)$ & 0 & $15(93.8)$ & 0 & 0 & 0 & $16(100)$ \\
\hline \multirow{4}{*}{ 状 } & 南 & 0 & 0 & 0 & 0 & $54(64.3)$ & $23(27.4)$ & $7(8.3)$ & 0 & $84(100)$ \\
\hline & 南西角 & 0 & 0 & 0 & 0 & $17(81.0)$ & $1(4.8)$ & $3(14.3)$ & 0 & $21(100)$ \\
\hline & 西 & 0 & 0 & 0 & 0 & $19(76.0)$ & $2(8.0)$ & $4(16.0)$ & 0 & $25(100)$ \\
\hline & 合計 & $5(1.9)$ & $16(6.1)$ & $9(3.4)$ & $3(1.1)$ & $168(63.9)$ & $41(15.6)$ & $20(7.6)$ & $1(0.4)$ & $263(100)$ \\
\hline
\end{tabular}


「目線高さ」が増加し、高さが低下する傾向にある。なお、現状と理想との 関係性は高く、現状＝理想の選択が最も多いが、次位はおおむね「目線 高さ」になる。家側から見た高さの理想は「腰の高さ」が最も多く、次いで 「目線高さ」である。道路側同様に現状と強い関係性があるが、腰の高さ より低い場合には現状よりもわずかながら高い方を選択する傾向がある。

\section{2) 隣家側}

「腰の高さ」が $58.1 \%$ と最も多く、次いで「目線高さ」で、道路側家面と 類似の順位を示している。理想は「目線高さ」が最も多く、次いで「腰の 高さ」であり、「目線高さ」が増加しているが、現状と強い関連性を示し、 現状＝理想が最も多い。しかし、次位としては「目線高さ以上小以外は現 状よりも高くすることを望む傾向にある。

\section{3）裏家側}

隣家側同様に「腰の高さ」が最も多く $(45.7 \%)$ 、次いで「目線高さ以 上」や「目線高さ」で、道路側家面や隣家側より「目線高さ以上」が多い。 理想は「目線高さ」が最も多く、次いで「腰の高さ」であり「目線高さ」が増 加しているが、隣家側同様現状と強い関連性を示し、現状＝理想が最も 多い。しかし、次に選ぶのは「目線高さ」で、「目線高さ以上小以外は現状 よりも高くすることを望む傾向にある。なお、現状が「目線高さ以上」の場 合も次位は「目線高さ」である。

4）四周の高さの関連性

以上より、道路側は現状も理想も「目線高さ以上」であり、道路側家面 ・隣家側・裹家側の現状は「腰の高さ」で、理想は道路側家面が「腰の高 さ、他は「目線高さ」となり、いずれも現状より高くなることを望んでいる。 これは道路側からは目線の高さ以上で、侵入を困難にし、家面について は閉鎖感を和らげるために腰程度の高さに抑える。同時に、隣家側や裏 家側に対しても閉鎖感の低减を図るためにか腰の高さ程度にとどめてい るが、理想としては、隣家側・裏家側もさらに高くしたいと考えている。

しかし、居住者は道路側、隣家側、裏家側に対して同じような意識で 対処しているのだろうか。この傾向を知るため、戸別に四周の高さの現状 と理想を分析する。塀の高さは「その他」を除けば5種類となり、この組み 合わせで、合計 $5 \times 5 \times 5 \times 5(625)$ パターンがあり得ることになる。

その他、不明を除く213戸の現状についてその組み合わせを見ると、7 5 種類になり非常に多様なことを示している。最む多い組み合わせは「道 路側·道路側家面·隣家側·裹家側」の順で「目線高さ以上·腰の高さ·腰 の高さ・腰の高さ」で31戸、これは現状の最多値の組み合わせと同じであ る。その他、8戸以上がもつ組み合わせは6パターンで、7パターン合計8 4戸 $(39.4 \%)$ となる。理想では8戸以上がもつ組み合わせは少し增加し8 パターン(合計103戸 $/ 229$ 戸 $45.0 \%$ )、最大は「目線高さ・目線高さ・目 線高さ・目線高さ」で21戸である。なお、最大值による組み合わせ例(「目 線高さ以上・腰の高さ・目線高さ・目線高さ」)は少なく9戸にすぎない。ま

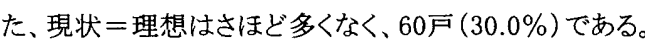

地盤の高さを考慮しなければ(すなわち、道路側・隣家側・裏家側から の高さだけ)、可能組み合わせは、理論的にも実態的にも減少し、現状 で9戸以上がもつ組み合わせは8パターン(合計155戸／229戸: 67.7 \%)、最大組み合わせは「目線高さ以上・腰の高さ・腰の高さ」60戸で、最 大值の組み合わせと同一である。理想は8戸以上がもつ組み合わせは8 パターン(159戸／240戸: $66.3 \%) 、$ 最大組み合わせは「目線高さ・目線 高さ・目線高さ」の35戸となるが、最大值の組み合わせ(「目線高さ以上・ 目線高さ・目線高さ」)次位で28戸である。現状二理想は79戸( $/ 220$ 戸: $35.9 \%$ )である。
次に、少し詳細に道路側、道路側家面、隣家側、裏家側の一対比較 を行うと(表5)、現状では「道路側 >裏家側 ミ隣家側」、道路側家面、隣 家側、裏家側については「道路側家面 >やくも見られるという傾向である。理想でも類似した傾向ではあ るが、道路側、道路側家面、隣家側、裏家側が同じ高さという割合が増 加する。大まかに大小関係を記述するならば、現状では「道路側＞董家

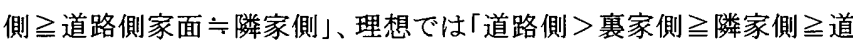
路側家面」の傾向が見受けられる。

\section{5）敷地方位別塀の高さ}

敷地方位別に四周の「塀の有無」「塀の高さ:現状と理想」との関係性 をみると(表6)、高さについては隣家側塀の理想のみ有意である( $x^{2}$ 判

表3 地盤高さの現状と理想

\begin{tabular}{|c|c|c|c|c|c|c|c|c|}
\hline & \multicolumn{4}{|c|}{ 理 } & \multicolumn{3}{|l|}{ 想 } \\
\hline & & 道路面 & $50 \mathrm{~cm}$ & $1.0 \mathrm{~m}$ & $1.5 \mathrm{~m}$ & $2 \mathrm{mW上}$ & わからない & 合 計 \\
\hline \multirow{4}{*}{ 現 } & 道路面 & $4(80.0)$ & 0 & $1(20.0)$ & 0 & 0 & 0 & $5(100)$ \\
\hline & $50 \mathrm{~cm}$ & $4(11.8)$ & $20(58.8)$ & $5(14.7)$ & 0 & I( 2.9) & $4(11.8)$ & $34(100)$ \\
\hline & $1.0 \mathrm{~m}$ & $8(8.8)$ & $16(17.6)$ & $47(51.6)$ & $9(9.9)$ & $4(4.4)$ & $7(7.7)$ & $91(100)$ \\
\hline & $1.5 \mathrm{~m}$ & $9(13.4)$ & $16(23.9)$ & $15(22.4)$ & $21(31.3)$ & $4(6.0)$ & $2(3.0)$ & $67(100)$ \\
\hline \multirow{3}{*}{ 状 } & $2 \mathrm{~m}$ 以上 & $9(15.0)$ & $7(11.7)$ & $12(20.0)$ & $5(8.3)$ & $21(35.0)$ & $6(10.0)$ & $60(100)$ \\
\hline & わからない & $1(10.0)$ & $1(10.0)$ & $2(20.0)$ & 0 & 0 & $6(60.0)$ & $10(100)$ \\
\hline & 計 & $35(13.1)$ & $60(22.5)$ & $82(30.7)$ & $35(13.1)$ & $30(11.2)$ & $25(9.4)$ & $267(100)$ \\
\hline
\end{tabular}

高さ注約 $\bigcirc \bigcirc \mathrm{m}$

表4 塀の高さの現状と理想

\begin{tabular}{|c|c|c|c|c|c|c|c|c|}
\hline & \multicolumn{7}{|c|}{ 理 想の高さ } \\
\hline & & & 約 $50 \mathrm{~cm}$ & 腰の高さ & 目線高さ & \begin{tabular}{|c|}
$\begin{array}{c}\text { 目線高さ } \\
\text { 以上 }\end{array}$ \\
\end{tabular} & その他 & \\
\hline & な & $6(46.2)$ & $1(7.7)$ & $2(15.4)$ & $3(23.1)$ & $1(7.7)$ & 0 & $13(100)$ \\
\hline & 約 $50 \mathrm{~cm}$ & 0 & $1(33.3)$ & $1(33.3)$ & 0 & 1(33.3) & - & $3(100)$ \\
\hline 道 & 腰の高さ & 0 & 0 & $6(50.0)$ & $5(41.7)$ & $1(8.3)$ & 0 & $12(100)$ \\
\hline 路 & 目線 高さ & $4(7.7)$ & 0 & $1(1.9)$ & $41(78.8)$ & $5(9.6)$ & $1(1.9)$ & $52(100)$ \\
\hline 側 & 目線高さ以上 & $3(1.8)$ & 0 & $8(4.7)$ & $48(28.2)$ & $107(62.9)$ & $4(2.4)$ & $170(100)$ \\
\hline & その他 & $1(20.0)$ & 0 & 0 & 0 & 0 & $4(80.0)$ & $5(100)$ \\
\hline & 合、計 & $14(5.5)$ & $2(0.8)$ & $18(7.1)$ & $97(38.0)$ & $115(45.1)$ & $9(3.5)$ & $255(100)$ \\
\hline & な & $7(46.7)$ & $1(6.7)$ & $4(26.7)$ & $2(13.3)$ & $1(6.7)$ & 0 & $15(100)$ \\
\hline 道 & 約 $50 \mathrm{~cm}$ & 0 & $12(57.1)$ & $5(23.8)$ & $4(19.0)$ & 0 & 0 & $21(100)$ \\
\hline & 腰の高さ & $5(4.6)$ & $1(0.9)$ & $84(77.1)$ & 13(11.9) & $5(4.6)$ & $1(0.9)$ & $109(100)$ \\
\hline 側 & 目線高さ & $1(1.5)$ & 0 & $6(9.2)$ & $53(81.5)$ & $5(7.7)$ & 0 & $65(100)$ \\
\hline 家 & 目線高さ以上 & 0 & 0 & $2(8.7)$ & $6(26.1)$ & $15(65.2)$ & O & $23(100)$ \\
\hline 面 & その他 & 0 & 0. & $3(27.3)$ & $5(45.5)$ & 0 & $3(27.3)$ & $11(100)$ \\
\hline & 合 & $13(5.3)$ & $14(5.7)$ & $104(42.6)$ & $83(34.0)$ & $26(10.7)$ & $4(1.6)$ & $244(100)$ \\
\hline & な & $3(50.0)$ & 의 & $2(33.3)$ & $1(16.7)$ & 이 & 의 & $6(1009$ \\
\hline & 約 $50 \mathrm{~cm}$ & 0 & $11(64.7)$ & $3(17.6)$ & $3(17.6)$ & 0 & 0 & $17(100)$ \\
\hline 隣 & 腰の高さ & $3(1.9)$ & $1(0.6)$ & $88(57.1)$ & $53(34.4)$ & $8(5.2)$ & $1(0.6)$ & $154(100)$ \\
\hline 家 & 目線 高さ & 0 & 0 & $2(3.6)$ & $44(78.6)$ & $10(17.9)$ & 0 & $56(100)$ \\
\hline 側 & 目線高さ以上 & 0 & 의 & $3(15.0)$ & $3(15.0)$ & $14(70.0)$ & 01 & $20(100)$ \\
\hline & その他 & 0 & 0 & $3(25.0)$ & $7(58.3)$ & 0. & $2(16.7)$ & $12(100)$ \\
\hline & 計 & $6(2.3)$ & $12(4.5)$ & $101(38.1)$ & $111(41.9)$ & $32(12.1)$ & $3(1.1)$ & 265(100) \\
\hline & な & $2(50.0)$ & 0 & 0 & $2(50.0)$ & ㅇ. & 0 & 4(100) \\
\hline & 約 $50 \mathrm{~cm}$ & 0 & $6(42.9)$ & $2(14.3)$ & $5(35.7)$ & $1(7.1)$ & 0 & $14(100)$ \\
\hline & 腰の高さ & $1(0.8)$ & $2(1.7)$ & $69(58.5)$ & $36(30.5)$ & $9(7.6)$ & $1(0.8)$ & $118(1009$ \\
\hline 家 & 目線高さ & 0 & 0 & $7(13.0)$ & $41(75.9)$ & $5(9.3)$ & $1(1.9)$ & $54(100)$ \\
\hline 側 & 目線高さ以上 & 0 & 0 & $1(1.7)$ & $16(27.6)$ & $40(69.0)$ & $1(1.7)$ & $58(100)$ \\
\hline & ₹ $\sigma$ 他 & 0 & 0 & $2(20.0)$ & $4(40.0)$ & 0 & $4(40.0)$ & $10(100)$ \\
\hline & 合 & $3(1.2)$ & $8(3.1)$ & $81(31.4)$ & $104(40.3)$ & $55(21.3)$ & $7(21.3)$ & $258(100)$ \\
\hline
\end{tabular}

表5 塀の高さ比較

\begin{tabular}{|c|c|c|c|c|c|}
\hline & \multicolumn{4}{|l|}{ 現 } \\
\hline & & 隣家側 & 裏家側 & 隣家側 & 裏家側 \\
\hline \multirow{3}{*}{$\begin{array}{l}\text { 道 } \\
\text { 路 } \\
\text { 側 }\end{array}$} & $>$ & 75.9 & 63.0 & 53.2 & 48.8 \\
\hline & $=$ & 17.8 & 27.7 & 36.3 & 37.1 \\
\hline & $<$ & 6.2 & 9.2 & 10.5 & 14.2 \\
\hline \multirow{3}{*}{$\begin{array}{l}\text { 家道 } \\
\text { 面路 } \\
\text { 側 }\end{array}$} & $>$ & 23.4 & 23.8 & 15.4 & 12.7 \\
\hline & $=$ & 55.0 & 38.8 & 57.9 & 51.9 \\
\hline & $<$ & 21.6 & 37.4 & 26.7 & 35.4 \\
\hline \multirow{3}{*}{$\begin{array}{l}\text { 隣 } \\
\text { 家 } \\
\text { 側 }\end{array}$} & $>$ & - & 11.1 & - & 8.3 \\
\hline & $=$ & - & 57.0 & - & 68.8 \\
\hline & $<$ & - & 32.0 & - & 22.9 \\
\hline
\end{tabular}


定で危険率 5\%) が、敷地方位の南と北のみで比較すると、道路側のみ、 現状、理想とも南の塀の方が高い傾向が見られる( $x^{2}$ 判定で危険率 5 $\%$ 。

\section{（2）塀の種類}

図2のような凡例を示し、どのような種類の塀に囲まれているかを調査 した結果が表7である。

\section{1) 道路側}

現状で最も多いのは「竪格子・横栈」、次いで「フェンス・ネット」であ る。「コンクリート・ブロック」や「生け垣」以外は視線透過性の良い材料で あり、これらは全体の $67.7 \%$ (その他除く)にもなる。理想の種類は「生け 垣」(23.5\%) や「ミックス」 (21.5\%)が多く、「竪格子・横栈」や「フェンス・ ネットの割合が低下している。いずれの場合も、現状と同じ種類を理想 とするものが多いが、次に多い選択として「スリット」や堅格子・横栈」が 「生什垣」を、「フェンス・ネットかが「ミックス」や「生け垣」を選んでいるのが 特徴的であり、いずれも視線透過性の低下を考えていると推察できる。 お、「ミックス」が「ミックス」を、「コンクリート・ブロック」が「コンクリート・ブロ ック」を選ぶ比率が高いのも特徴的といえる。

高さは、前述のように道路側現状・理想とも「目線高さ以上」や「目線高 さ」が多いが(小計は現状 $87.1 \%$ 、理想83.1\%)、「コンクリート・ブロック」 や「生け垣」など視線透過性の低さをも併せ持つものは現状69(27.0 \%)、理想82(35.2\%) と比較的少ない。なお、理想の方が現況より多くな っている。

\section{2) 隣家側}

隣家側は「フェンス・ネット」が $48.6 \%$ と非常に多く、次いで「竪格子・横 栈」(22.7\%)であり、合計71.4\%になる。いずれも、視線透過性が高いの が特徵的である。「コンクリート・ブロック」「スリット」「ミックス」などハードな 塀は少ない $(16.9 \%)$ 。理想の種類は「フェンス・ネットが多いが (34.1 \%)、他は分散している。しかし現状と比較すると同じ種類の選択率は高 いが、「フェンス・ネット」や「竪格子・横栈」が減少し、「生け垣」や、「コン
クリート・ブロック」「スリット」ミックス」などの選択が高くなっている。

「目線高さ」以上で視線透過性の低い材料は、現状 $27(11.5 \%) 、$ 理想 $52(20.7 \%) て ゙ 、$ 道路側に比べて低いが、現状に比べ理想は約2倍で、プ ライバシー確保の希望が伺える。

3） 裏家側

裏家側は隣家側と同様に「フェンス・ネット」が $44.2 \%$ と非常に多く、次 表 6 敷地方位別塀の有無・高さ·種類 $\chi 2$ 検定

\begin{tabular}{|c|c|c|c|}
\hline & & P値 & 判定 \\
\hline \multirow{5}{*}{ 道路側 } & 塀の有無 & 0.1493 & . \\
\hline & 䄯の高さ & 0.2928 & - \\
\hline & 塀の高さ:理想 & 0.4165 & - \\
\hline & 垪の種穎 & 0.8690 & - \\
\hline & 塀の種類: 理䄷 & 0.0799 & - \\
\hline \multirow{2}{*}{ 道路側: 家面 } & 境の高さ & 0.8330 & - \\
\hline & 墱の高さ:理想 & 0.6138 & - \\
\hline \multirow{5}{*}{ 隣家側 } & 塀の有無 & 0.5189 & - \\
\hline & 垪の高さ & 0.8699 & - \\
\hline & 塀の高さ:理想 & 0.0419 & * \\
\hline & 塀の種類 & 0.2761 & - \\
\hline & 塀の種類: 理想 & 0.3299 & - \\
\hline \multirow{5}{*}{ 裏家側 } & 塀の有無 & 0.6572 & - \\
\hline & 墱の高さ & 0.7053 & 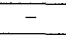 \\
\hline & 垠の高さ:理想 & 0.7936 & - \\
\hline & 塀の種類 & 0.0219 & * \\
\hline & 塀の種類:理想 & 0.0650 & - \\
\hline
\end{tabular}

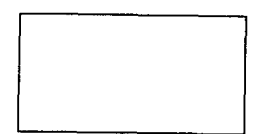

1) コンクリートやフロック

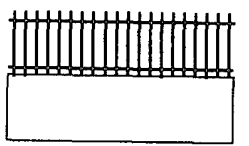

4) 㹂格子+十横栈

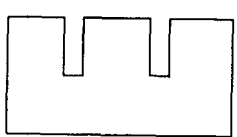

2) ズリット

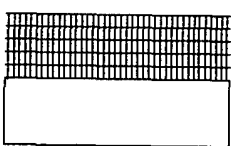

5) フエンスやネット

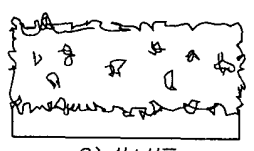

3) 生提

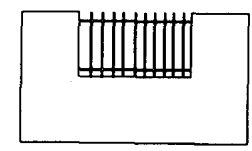

6) ミックス
図2 塀の種類: 調査用凡例

表7 塀の種類の現状と理想

\begin{tabular}{|c|c|c|c|c|c|c|c|c|c|c|}
\hline & \multicolumn{9}{|c|}{ 理想の種類 } \\
\hline & & $\begin{array}{l}\mathrm{RC} \cdot \\
\text { ブロック }\end{array}$ & スリット & 生け垣 & $\begin{array}{l}\text { 鋻格子 } \\
\text { •横栈 }\end{array}$ & $\begin{array}{l}\text { フェンス } \\
\text { ·ネット }\end{array}$ & ミックス & なし & その他 & 合計 \\
\hline & $\mathrm{RC} \cdot$ ブロック & $20(57.1)$ & $2(5.7)$ & $4(11.4)$ & $1(2.9)$ & $1(2.9)$ & $5(14.3)$ & $1(2.9)$ & $1(2.9)$ & $35(100)$ \\
\hline & スリッ卜 & 0 & $2(28.6)$ & $2(28.6)$ & $1(14.3)$ & 0 & $1(14.3)$ & $1(14.3)$ & 0 & $7(100)$ \\
\hline & 生け垣 & $5(13.5)$ & $3(8.1)$ & $19(51.4)$ & $1(2.7)$ & $1(2.7)$ & $4(10.8)$ & $1(2.7)$ & (8.1) & $37(100)$ \\
\hline 道 & 堅格子·横栈 & $2(3.4)$ & $3(5.2)$ & $10(17.2)$ & $22(37.9)$ & $9(15.5)$ & $9(15.5)$ & $3(5.2)$ & 0 & $58(100)$ \\
\hline 路 & フエンス・ネット & $3(6.3)$ & $1(2.1)$ & $13(27.1)$ & $1(2.1)$ & $15(31.3)$ & $13(27.1)$ & $2(4.2)$ & 0 & $48(100)$ \\
\hline 側 & ミックス & 0 & $1(3.7)$ & $3(11.1)$ & $3(11.1)$ & $2(7.4)$ & $18(66.7)$ & & & \\
\hline & なし & $3(27.3)$ & 0 & $2(18.2)$ & $1(9.1)$ & 1( 9.1$)$ & 0 & $4(36.4)$ & 0 & $11(100)$ \\
\hline & その他 & $4(14.3)$ & $1(3.6)$ & $6(21.4)$ & $1(3.6)$ & $8(28.6)$ & $4(14.3)$ & 0 & $4(14.3)$ & $28(100)$ \\
\hline & 合計 & $37(14.7)$ & $13(5.2)$ & $59(23.5)$ & $31(12.4)$ & $37(14.7)$ & $54(21.5)$ & $12(4.8)$ & $8(3.2)$ & $251(100)$ \\
\hline & RC・ブロック & $17(60.7)$ & 0 & $2(7.1)$ & $4(14.3)$ & $1(3.6)$ & $2(7.1)$ & 0 & $2(7.1)$ & $28(100)$ \\
\hline & スリット & 0 & 0 & $1(50.0)$ & 0 & $1(50.0)$ & $\pi$ & 0 & 0 & $2(100)$ \\
\hline & 生け垣 & $\overline{0}$ & 0 & $6(60.0)$ & $3(30.0)$ & 0 & $\mathrm{I}(10.0)$ & 0 & 0 & $10(100)$ \\
\hline 隣 & 㹂格子·横栈 & $3(5.2)$ & $3(5.2)$ & $5(8.6)$ & $33(56.9)$ & $11(19.0)$ & $2(3.4)$ & $1(1.7)$ & 0 & $58(100)$ \\
\hline 家 & フェンス・ネット & $5(4.0)$ & $6(4.8)$ & $17(13.7)$ & $4(3.2)$ & $69(55.6)$ & $19(15.3)$ & $2(1.6)$ & $2(1.6)$ & $124(100)$ \\
\hline 側 & シックス & $4(30.8)$ & 0 & $1(7.7)$ & $1(7.7)$ & $1(7.7)$ & $6(46.2)$ & 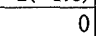 & 等 & $13(100)$ \\
\hline & なし & $1(33.3)$ & 0 & & 0 & $1(33.3)$ & 0 & $1(33.3)$ & 0 & $3(100)$ \\
\hline & その他 & $3(17.6)$ & $1(5.9)$ & $3(17.6)$ & $1(5.9)$ & $3(17.6)$ & $2(11.8)$ & Thos & $4(23.5)$ & $17(100)$ \\
\hline & 合計 & \begin{tabular}{|l|}
$33(12.9)$ \\
\end{tabular} & $10(3.9)$ & $35(13.7)$ & $46(18.0)$ & $87(34.1)$ & $32(12.5)$ & $4(1.6)$ & $8(3.1)$ & $255(100)$ \\
\hline & 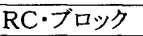 & $23(56.1)$ & $2(4.9)$ & $4(9.8)$ & $4(9.8)$ & $2(4.9)$ & $5(12.2)$ & 0 & $1(2.4)$ & $41(100)$ \\
\hline & スリット & $1(50.0)$ & 0 & 0 & $1(50.0)$ & 0 & 0 & 0 & 0 & $2(100)$ \\
\hline & 生け塇 & $2(14.3)$ & $2(14.3)$ & $5(35.7)$ & $2(14.39$ & $2(14.3)$ & $1(7.1)$ & 0 & 0 & $14(100)$ \\
\hline 裏] & 㹂格子・横栈 & $4(7.5)$ & $3(5.7)$ & $5(9.4)$ & $26(49.1)$ & $9(17.0)$ & $3(5.7)$ & $1(1.9)$ & $2(3.8)$ & $53(100)$ \\
\hline 豕 & フメンス・ネット & $11(9.9)$ & $3(2.7)$ & $14(12.6)$ & $5(4.5)$ & $63(56.8)$ & $10(9.0)$ & $1(0.9)$ & $4(3.6)$ & $111(100)$ \\
\hline 側 & シックス & $1(9.1)$ & 0 & $2(18.2)$ & 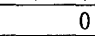 & $1(9.1)$ & $7(63.6)$ & 8 & 4 & $11(100)$ \\
\hline & なし & $1(25.0)$ & 0 & & $1(25.0)$ & 0 & $1(25.0)$ & $1(25.0)$ & & $4(100)$ \\
\hline & その他 & $1(6.7)$ & 0 & $6(40.0)$ & 0 & 0 & 0 & 0 & $8(53.3)$ & $15(100)$ \\
\hline & 合計 & $44(17.5)$ & $10(4.0)$ & $36(14.3)$ & $39(15.5)$ & $77(30.7)$ & $27(10.8)$ & $3(1.2)$ & $15(6.0)$ & $251(100)$ \\
\hline
\end{tabular}


いで「竪格子・横栈」(21.1\%)であり、合計 $65.3 \%$ になる。理想の種類は 「フェンス・ネット」が多く $(30.7 \%)$ 、他が分散しているのも隣家側と同様の 傾向である。また、現状と同じ種類の選択率は高いが、「フェンス・ネッ 卜やや㹂格子・横栈」が減少し、「生け垣」や「スリット「ミックス」などの選 択が高くなっている。

「目線高さ」以上で視線透過性の低い材料は、現状 $43(18.6 \%) 、$ 理想 65(27.4\%)で、道路側よりは低いが隣家側よりも高くなっている。

\section{4）四周の種類の関連性}

高さ同様に種類についても四周の関連性を考えると $8^{3}=512$ 通りの 組み合わせがある。現状も 92 パターン(223戸) と非常に多様であり、最も 多い組み合わせでも四周「フェンス・ネット(30戸)、次いで四周「㹂格子 •横栈」(17戸)である。8戸以上がもつ組み合わせは6種類で計 91 戸 $(40$. 8\%)になる。理想でも106パターン(238戸) とさらに多様で、組み合わせ も分散し、最も多いのが四周「フェンス・ネット」(18戸)、次いで四周「コン クリート・ブロック」(16戸)、道路面「生け垣」で他は「フェンス・ネット」(16 戸)、四周「生け垣」(15戸)等が続く。10戸以上がもつ組み合わせは7 7 種

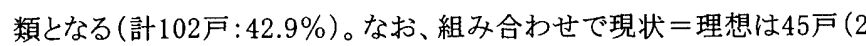
$2.5 \%)$ ので非常に少ないが、特徽的なのは四周「コンクリート・ブロッ ク」で、現状8戸の内、7戸までが理想として選んでいる。また、四周同じ 種類というのも比較的多く現状 61 戸 $(27.4 \%)$ 、理想80戸(33.6\%)となる。

道路側、隣家側、裹家側それぞれについて一対比較を行うと、「道路 側 $=$ 隣家側、裏家側」は現状でそれぞれ $39.6 \%$ 、35.7\%、理想で 44.0 \%、45.1\%となる。また、「隣家側＝董家側」は現状で $68.9 \%$ 、理想で 64. $3 \%$ となり、道路側に比較して隣家側、裏家側の同一性は高い。

5）その他

(1)住宅は昭和58年から建設されているが、建設年度と各面の塀の種 類 (現状)とは有意に関連性が見られる( $x^{2}$ 判定で危険率 $\left.1 \%\right)$ 。全体的 傾向としては、道路側では「コンクリート・ブロック」と「堅格子・横栈」が平 成 10 年以降激减し、「フェンス・ネット」が平成5年以降増加している。隣 家側では「コンクリート・ブロック」が平成 5 年以降、「竪格子・横栈」が平 成 10 年以降减少し、「フンンス・ネット」が平成 5 年以降增加している。裏 家側では「コンクリート・ブロック」が平成 5 年以降、「朢格子・横栈」が平 成 10 年以降減少し、「フェンス・ネット」が平成 10 年以降增加している。こ のように時期は異なるが、「コンクリート・ブロック」や「竪格子・横栈」は減 少し、「フェンス・ネットが増大する傾向にある。

(2)敷地方位と塀の種類 (現状および理想)とは「裹家側塀の種類」( $x^{2}$ 判定で危険率5\%) 以外は有意な関係は見られないが(表6)、敷地方位 の南と北との違いを比べてみると、道路側については、現状で南は「生け 垣」、北は「ミックス」や「なし小、理想は南に「コンクリート・ブロック」が、北 に「スリット」や「なし」が多く見られる。北はプランとも関連し、建物が塀を 兼ねる場合もあると考えられる。隣家側については、現状で南は「フェン ス・ネット、北は「朢格子・横栈」が多く、理想では南が「コンクリート・ブロ ック」と「ミックス」、北が「竪格子・横栈」が多いが、その理由は不明であ る。裹家側は現状、理想とも南は「フェンス・ネット」が、北は「生け垣」「㹂 格子・横栈」が多いが、日照や修景を考魔してのことと考えられる。

3-4 プライバシー感

以上の様に、敷地の四周は塀によって囲まれていることが多く、かつ、 その高さも道路からは侵入を困難とする高さ、隣地からもそのような高さ が理想とされているが、塀の種類は視覚的透過性が高いものが多い。本 節は居住者の四周からの視覚的侵犯に対する抵抗感を「非常に気にな
るかから全く気にならないまでの7段階評価で分析しようとするものであ り、見られる場所としては「庭の中」および「家の中」を、見る場所としては 「道路」から、門屝から玄関までの「アプローチ」から、「隣家」から、「毫 家」からとし、見える程度は実態ではなく、仮定された見え方で「ほとんど 見える」「半分くらい見える」ららほら見える」「ほとんど見えない」想定 する(表8)。

\section{（1）庭の中への視線}

「道路」「アプローチ」「隣家」「裏家」、いずれからも「ほとんど見える」か ら「ほとんど見えない」まで、見える程度が低くなるにつれて気になる程度 が逓减している。「道路」からの視線が最も気になる程度が高いと感じら れ、「ほとんど見える」や「半分くらい見える」では「気になる」が最も多く、 それぞれ $39.4 \%$ 、37.4\%になり、次いで「少し気になる」になる。「ちらほら 見える」程度でも「まり気にならない」 $(42.0 \%)$ が多いものの、「少し気 になる」 $18.7 \%$ 見られる。「ほとんど見えない」場合には「全く気にならな いが $62.7 \%$ になるが、それでも「少し気になる」程度以上が $7.6 \%$ 見ら れ、庭やプライバシー、防犯に関しての自由意見にも多く見られるが、 「相手から見られない」=「庭の中への他人の侵入が外から見えないり いうことで、防犯的に心配があり、プライバシーとの間に矛盾・葛藤がある ことが示唆される。

「アプローチ」からも「道路」と同様に莪減するが、「半分くらい見える」 場合は「少し気になる」が最も多く「あり気にならないが次位と、気にな る程度が低下の傾向にある。また「ちらほら見える」も「あり気にならな

表8 プライバシー感

\begin{tabular}{|c|c|c|c|c|c|c|c|c|c|}
\hline & \multicolumn{4}{|c|}{ 庭の中 } & \multicolumn{4}{|c|}{ 家の中 } \\
\hline & & $\begin{array}{l}\text { ほとん } \\
\text { ど見え } \\
\text { る }\end{array}$ & $\begin{array}{l}\text { 半分 } \\
\text { らい見 } \\
\text { える }\end{array}$ & $\begin{array}{c}\text { ちらほ } \\
\text { ら見え } \\
\text { る }\end{array}$ & $\begin{array}{l}\text { ほとん } \\
\text { ど見え } \\
\text { ない }\end{array}$ & $\begin{array}{l}\text { ほとん } \\
\text { ど見え } \\
\text { る }\end{array}$ & $\begin{array}{l}\text { 半分 } \\
\text { らい見 } \\
\text { える }\end{array}$ & $\begin{array}{c}\text { ちらほ } \\
\text { ら兒え } \\
\text { る }\end{array}$ & $\begin{array}{l}\text { ほとん } \\
\text { ど見え } \\
\text { ない }\end{array}$ \\
\hline \multirow{7}{*}{ 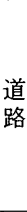 } & 非常に気になる & 13.9 & 3.4 & 0.5 & 0.9 & 63.4 & 35.7 & 10.5 & 0.9 \\
\hline & 気になる & 39.4 & 37.4 & 7.8 & 3.1 & 27.3 & 42.9 & 22.9 & 1.7 \\
\hline & 少し気になる & 21.6 & 24.3 & 18.7 & 3.6 & 4.6 & 13.3 & 38.1 & 5.7 \\
\hline & どちらでもない & 2.4 & 5.3 & 7.3 & 2.2 & 1.5 & 1.5 & 5.2 & 3.5 \\
\hline & あまり気にならない & 13.0 & 13.6 & 42.0 & 8.0 & 1.0 & 4.1 & 17.6 & 14.4 \\
\hline & 気にならない & 4.8 & 8.7 & 12.8 & 19.6 & 1.0 & 1.0 & 2.9 & 24.0 \\
\hline & 全く気にならない & 4.8 & 7.3 & 11.0 & 62.7 & 1.0 & 1.5 & 2.9 & 49.8 \\
\hline \multirow{7}{*}{$\begin{array}{l}\text { ア } \\
\text { プ } \\
\square \\
\text { l } \\
\text { チ }\end{array}$} & 非常に気になる & 8.2 & 4.1 & 1.5 & 0.5 & 40.5 & 26.0 & 6.4 & 1.3 \\
\hline & 気になる & 28.0 & 18.0 & 5.4 & $2 . \overline{0}$ & 34.9 & 31.8 & 16.3 & 1.3 \\
\hline & 少し気になる & 17.9 & 24.7 & 11.2 & 4.0 & 13.3 & 27.6 & 30.7 & 4.8 \\
\hline & どちらでもない & 3.9 & 5.2 & 10.7 & 4.0 & 1.5 & 2.6 & 10.9 & 4.8 \\
\hline & あまり気にならない & 18.8 & 20.6 & 31.7 & 10.4 & 5.6 & 6.8 & 25.7 & 14.7 \\
\hline & 気にならない & 8.7 & 13.4 & 18.0 & 13.9 & 2.1 & 3.6 & 5.9 & 22.5 \\
\hline & 全く気にならない & 14.5 & 13.9 & 21.5 & 65.2 & 2.1 & 1.6 & 4.0 & 50.6 \\
\hline \multirow{7}{*}{$\begin{array}{l}\text { 隣 } \\
\text { 家 }\end{array}$} & 非常に気になる & 11.1 & 4.8 & 2. & 0.5 & 42.1 & 24.6 & 12.1 & 1.4 \\
\hline & 気になる & 22.7 & 19.8 & 5.9 & 0.5 & 36.9 & 40.5 & 16.8 & 1.4 \\
\hline & 少し気になる & 23.1 & 24.6 & 16.3 & 4.6 & 14.9 & 24.1 & 32.2 & 5.4 \\
\hline & どちらでもない & 1.3 & 5.8 & 8.9 & 3.0 & 1.0 & 2.6 & 9.8 & 3.2 \\
\hline & あまり気にならない & 19.6 & 19.3 & 27.2 & 12.2 & 2.6 & 5.6 & 18.2 & 15.4 \\
\hline & 気にならない & 12.0 & 11.6 & 15.8 & 13.2 & 1.0 & 2.1 & 6.5 & 21.3 \\
\hline & 全く気にならない & 10.2 & 14.0 & 23.8 & 66.0 & 1.5 & 0.5 & 4.2 & 52.0 \\
\hline \multirow{7}{*}{$\begin{array}{l}\text { 裏 } \\
\text { 家 }\end{array}$} & 非常に気になる & 11.6 & 6.1 & 1.5 & 1.4 & 42.1 & 23.8 & 11.7 & 1.8 \\
\hline & 気になる & 21.7 & 18.2 & 5.1 & 1.0 & 40.0 & 44.0 & 18.3 & 0.5 \\
\hline & 少し気になる & 28.0 & 25.8 & 14.7 & 2.4 & 11.8 & 24.9 & 32.4 & 6.0 \\
\hline & どちらでもない & 1.9 & 7.1 & 9.6 & 2.9 & 1.0 & 0.5 & 9.4 & 6.0 \\
\hline & あまり気にならない & 17.9 & 18.2 & 27.9 & 12.9 & 2.6 & 5.2 & 20.2 & 13.8 \\
\hline & 気にならない & 8.7 & 12.1 & 16.2 & 12.9 & 1.0 & 1.0 & 5.2 & 19.7 \\
\hline & 全く気にならない & 10.1 & 12.6 & 24.9 & 66.7 & 1.5 & 0.5 & 2.8 & 52.3 \\
\hline$\overline{\text { 平 }}$ & 道 路 & 5.05 & 4.56 & 3.35 & 1.77 & 6.43 & 5.95 & 4.83 & 2.00 \\
\hline \multirow{2}{*}{ 均 } & アプローチ & 4.19 & 3.84 & 2.94 & 1.76 & 5.89 & 5.51 & 4.33 & 2.00 \\
\hline & 隣 家 & 4.28 & 3.94 & 3.04 & 1.71 & 6.06 & 5.68 & 4.58 & 1.98 \\
\hline & 裏 家 & 4.41 & 4.00 & 2.94 & 1.70 & 6.09 & 5.76 & 4.65 & 2.02 \\
\hline & ら道見知らぬ & 78.1 & 69.7 & 61.9 & 13.0 & 87.1 & 85.5 & 76.6 & 22.1 \\
\hline & れ路 通行人 & 68.8 & 63.8 & 29.9 & 7.3 & 82.5 & 79.2 & 61.4 & 17.4 \\
\hline & てか 近所の人 & 40.1 & 27.7 & 18.0 & 4.1 & 76.6 & 68.8 & 47.8 & 16.8 \\
\hline & 気 5 隣人 & 22.4 & 17.0 & 10.8 & 3.1 & 56.1 & 48.6 & 33.2 & 10.5 \\
\hline & に見なし & 10.9 & 15.4 & 24.7 & 85.0 & 2.3 & 2.9 & 8.2 & 70.0 \\
\hline
\end{tabular}

備考 1) 值は\% 2)母数は各項目で異なり、193〜231。不明は除く 3) 平均得点 とは「非常に気になる」(7点)〜「全く気にならない（1点）の7段階評価の平均 
いが最も多く、次位は「全く気にならないリである。

「隣家」「裏家」は類似した傾向を示すが、「ほとんど見える」や「半分く らい見える」では「少し気になる」が最も多く、次位が「気になる」で、他は 「アプローチ」と類似の傾向が見られる。

以上が全体的な傾向であるが、気になる程度に応じて点を付けて判 断すると(「非常に気になる」7点〜「全く気にならない1点)、「道路」の 「ほとんど見える」や「半分くらい見える」の值が最も高く、次いで見える程 度が高いほど、また、同じ見え方ならおおむね、「裏家」〉「隣家」>「ア プローチ」の順で値が高い傾向が見受けられる。アプローチが低い理由 の1つは、来訪者の場合はおおむね用件がある人で、場合によっては門 前で対忘し、アプローチまで寄せ付けなくても良いことにもよる。

少し詳しく、各戸について4周からの感じ方を比較してみると(表 9 )、ど のような見え方にしても「道路」からが気になる程度が高く、次いで「裏 家」、隣家」、「アプローチ」の順になる。裹家」と「隣家」も同じ場合が多 く見られるものの、どちらかといえば「裏家」〉「隣家」である。四周同じに 感じる場合も22.7〜 62.9\%見られるが、見られる程度が高いほど全体に 気になる度合いが高く、ほとんど見えない場合のみ四周全く気にならな いが過半数となる。

\section{（2）家の中への視線}

「道路」「アプローチ」「隣家」「裏家」、いずれからも、庭の中への視線 と同様に「ほとんど見える」から「ほとんど見えないりまで、見える程度が低 くなるにつれて気になる程度が莪减しているが、「庭の中」よりも気になる 程度は全般に高いと考えられる。

「ほとんど見える」場合には、いずれからでも「非常に気になる」が最も 高く、特に「道路」からでは63.4\%にもなる。4万向とも「気になる」以上が8 $9.7 \%$ 75.4\%と非常に高い。「ちらほら見える」程度でも、「少し気にな る」以上が $53.4 \%$ 71.5\%と過半数である。「ほとんど見えない場合には 気になる程度は急激に低下し、「全く気にならないが $49.8 \%$ ～ $52.3 \%$ と なる。ただ、「庭の中」と同様にそれでも「少し気になる」程度以上が $8.3 \%$ 〜 $7.4 \%$ 見られる。
以上が全体的な傾向であるが、「庭の中」同様に気になる程度に応じ て点を付ける判断すると、見える程度に応じて「道路」〉「裹家」〉「隣家」 の順になるが、「アプローチ」のみ順位が少し低下の傾向にある。

各個人の4力所からの感じ方を比較してみると(表9)、どのような見え 方にしても「庭の中」同様、「道路」からが気になる程度が高く、次いで「裏 家」、隣家」、「アプローチ」の順になる。「裹家」と「隣家」もどちらかとい えば「裏家」〉隣家」であるが、「庭の中」に比較して同じ場合がより多 い。四周同じに感じる割合は、「ほとんど見える」〉「半分〈らい見える」〉 「ちらほら見える」と減少するが、「ほとんど見えない」でまた過半数に増 加する。これは、「ほとんど見える」場合には四周とも「非常に気になる」が 多く、「半分くらい見える」場合は「非常に気になる」や「気になる」が多い のに対し、「ちらほら見える」では順位や判断が分散し、「ほとんど見えな い場合には「全く気にならない」(39.2\%)や「あまり気にならない」気に ならないが多いことによる。

（3）道路から見られて困る人

見られて困る人は、見られる対象や見え方の状況によって異なる。気 になる程度と同様であるが、「家の中」が見える状況は、「庭の中」が見え る状況に比べて気になる人の存在が大きい。特に気になる程度の高い 道路からについて見ると(表 8$) 、$ 気になる人は「見知らぬ人」>「通行人」 $>$ 「近所の人」>「隣人」の順で、よく見えるほど、それぞれの比率が高く なる。家の中が半分くらい見られると、たとえ隣人であっても $48.6 \%$ 落、ち らほら程度でも $33.2 \%$ が気にしている。気になる人が無いという回答は、 家の中では「ほとんど見えない場合」 $(70.0 \%) 、$ 庭の中では同じく「ほとん ど見えない場合」(85.0\%)であり、これら以外は誰かを気にして生活して いるものが多い。

3-5 庭に面する部屋とその開口部の遮蔽

庭の中はともかくとしても、家の中が見られる抵抗感はかなり大きいこと がわかったが、実際、庭にはどのような部屋が面しており、それらの部屋 はどのような視覚的防御がなされているのであろうか。

1階で庭に面する部屋の $86.6 \%$ は居間、そのほかの部屋も和室 $(11.2$

表9 プライバシ一感比較

\begin{tabular}{|c|c|c|c|c|c|c|c|c|c|c|}
\hline & \multicolumn{4}{|c|}{ 庭の中 } & \multicolumn{4}{|c|}{ 家の中 } \\
\hline & & & ほとんど見える & 半分くらい見える & ちらほら見える & ほとんど見えない & ほとんど見える & 半分くらい見える & ちらほら見える & ほとんど見えない \\
\hline \multirow{17}{*}{ 評 } & \multirow{8}{*}{$\begin{array}{l}\text { す } \\
\text { で } \\
\tau \\
\text { 同 } \\
\text { 己゙ }\end{array}$} & 7777 & $6(3.4)$ & $3(1.7)$ & $1(0.6)$ & - & $54(29.0)$ & $27(14.6)$ & $9(4.8)$ & - \\
\hline & & 6666 & $14(7.9)$ & $7(4.0)$ & $2(1.1)$ & $1(0.6)$ & $26(14.0)$ & $26(14.1)$ & $11(5.9)$ & . \\
\hline & & 5555 & $9(5.1)$ & $6(3.4)$ & $5(2.8)$ & $1(0.6)$ & $3(1.6)$ & $7(3.8)$ & $16(8.6)$ & $3(1.5)$ \\
\hline & & 4444 & - & $1(0.6)$ & $2(1.1)$ & - & - & -1 & $2(1.1)$ & $3(1.5)$ \\
\hline & & 333 & $10(5.6)$ & $5(2.8)$ & $14(7.9)$ & $3(1.7)$ & $1(0.5)$ & $2(1.1)$ & $10(5.4)$ & $7(3.6)$ \\
\hline & & 2222 & $4(2.3)$ & $7(4.0)$ & $8(4.5)$ & $13(7.3)$ & $1(0.5)$ & $1(0.5)$ & $2(1.1)$ & $19(9.8)$ \\
\hline & & 1111 & $7(4.0)$ & $11(6.3)$ & $16(9.0)$ & $94(52.8)$ & $1(0.5)$ & $1(0.5)$ & $2(1.1)$ & $76(39.2)$ \\
\hline & & 小計 & $50(28.2)$ & $40 \quad(22.7)$ & $48 \quad(27.0)$ & $112(62.9)$ & $86 \quad(46.2)$ & $64 \quad(34.6)$ & $52(28.0)$ & $108(55.7)$ \\
\hline & \multirow[t]{3}{*}{ 道 } & 最大例 & $34(19.2)$ & $44(25.0)$ & $39(21.9)$ & $18(10.1)$ & $28(15.1)$ & $31(16.8)$ & $36(19.4)$ & $17(8.8)$ \\
\hline & & $\geqq$ & $143(80.8)$ & $135(76.7)$ & $127(71.3)$ & $141(79.2)$ & $174(93.5)$ & $158(85.4)$ & $137(73.7)$ & $150(77.3)$ \\
\hline & & 最小例 & $8(4.5)$ & $12(6.8)$ & $14(7.9)$ & $10(5.6)$ & $5(2.7)$ & $14(7.6)$ & $14(7.5)$ & $12(6.2)$ \\
\hline & \multirow{3}{*}{$\begin{array}{l}\square ア 7 \\
1 \gamma \\
f\end{array}$} & 最大例 & $3(1.7)$ & $5(2.8)$ & $5(2.8)$ & $7(3.9)$ & $3(1.6)$ & $1(0.5)$ & $4(2.2)$ & $4(2.1)$ \\
\hline & & $\geqq$ & $97(54.8)$ & $80 \quad(45.5)$ & $92(51.7)$ & $138(77.5)$ & $121 \quad(65.1)$ & $126(68.1)$ & $84(45.2)$ & $138(71.1)$ \\
\hline & & 最小例 & $30(16.9)$ & $29(16.5)$ & $22(12.4)$ & $4(2.2)$ & $31 \quad(16.7)$ & $36(19.5)$ & $37(19.9)$ & $11(5.7)$ \\
\hline & \multirow[t]{3}{*}{ 隣 } & 最大例 & $7(4.0)$ & $5(2.8)$ & $6(3.4)$ & $2(1.1)$ & $1(0.5)$ & $3(1.6)$ & $6(3.2)$ & $7(3.6)$ \\
\hline & & $\geqq$ & $97 \quad(54.8)$ & $87 \quad(49.4)$ & $96(53.9)$ & $136(76.4)$ & 127 (68.3) & $114(61.6)$ & $109(58.6)$ & $136(70.1)$ \\
\hline & & 最小例 & $10(5.6)$ & $12(6.8)$ & $6(3.4)$ & $2(1.1)$ & $10(5.4)$ & $14(7.6)$ & $10(5.4)$ & $4(2.1)$ \\
\hline \multirow[t]{7}{*}{ 価 } & \multirow[t]{3}{*}{ 裏 } & 最大例 & $6(3.4)$ & $9(5.1)$ & $13(7.3)$ & $6(3.4)$ & $1(0.5)$ & $2(1.1)$ & $8(4.3)$ & $7(3.6)$ \\
\hline & & $\geqq$ & $99(55.9)$ & $95(54.0)$ & $100(56.2)$ & $138(77.5)$ & $128 \quad(68.8)$ & $123(66.5)$ & $121 \quad(65.1)$ & $144(74.2)$ \\
\hline & & 最小例 & $9(5.1)$ & $8(4.5)$ & $11(6.2)$ & $6(3.4)$ & $5(2.7)$ & $5(2.7)$ & $5(2.7)$ & $2(1.0)$ \\
\hline & \multicolumn{2}{|c|}{ 隣家>裏家 } & $19(10.7)$ & $15(8.5)$ & $21(11.8)$ & $9(5.1)$ & $10(5.4)$ & $13(7.0)$ & $15(8.1)$ & $12(6.2)$ \\
\hline & \multicolumn{2}{|c|}{ 隣家=裏家 } & $134(75.7)$ & $134(76.1)$ & $135(75.8)$ & $159(89.3)$ & $160(86.0)$ & $152(82.2)$ & $148(79.6)$ & $167(86.1)$ \\
\hline & \multicolumn{2}{|c|}{ 隣家<裏家 } & $24(13.6)$ & $27(15.3)$ & $22 \quad(12.4)$ & $10(5.6)$ & $16(8.6)$ & $20(10.8)$ & $23(12.4)$ & $15(7.7)$ \\
\hline & \multicolumn{2}{|c|}{ サンプル数 } & 177 & 176 & 178 & 178 & 186 & 185 & 186 & 194 \\
\hline & & & & & & & & & & Ф」「ほ \\
\hline
\end{tabular}


\%)や食堂、客間などで、空も開放的な掃き出し空形式になっているもの が非常に多く、全体で $89.6 \%$ になる。外部から庭を通して家を哯かれるこ とを極度に気にしているこれら居住者は、どのようにしてプライバシーを 守っているのだろうか。

表10によると、装備している空遮蔽物の組み合わせは 35 パターンと非 常に多いが、厚手のカーテン+レースのカーテン+雨戸」が最も多く32. $5 \%$ 、次いで「厚手のカーテン+レースのカーテン」(9.7\%)で、他は分散

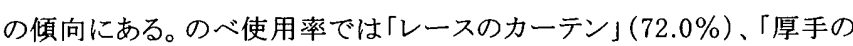
カーテン」 $(67.2 \%)$ および「雨戸」 $(60.4 \%)$ の3種類が非常に高い。

この様に多様な遮蔽物を備えた開放的な空であるが、昼間はその 81.8 $\%$ が遮蔽され、庭への視線を遮っている。遮蔽物はレースのカーテン $(5$ $3.2 \%)$ や薄手のカーテン $(17.6 \%)$ が多いが、厚手のカーテンや雨戸

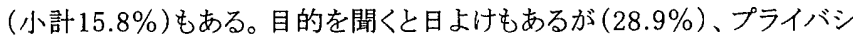

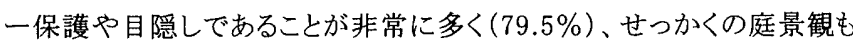
薄膜を通しての鑑賞にしかなり得ないことが多い。

\section{4 まとめ}

1. 理想の敷地方位は南東角、次は南面が希望されるが、南東角以外は 現状方位が肯定されることも多い。

2. 地盤の高さは $1 \mathrm{~m}$ 程度が最も多く、 $1.5 \mathrm{~m}$ 以上もおおむね半数程度見 られる。理想の高さも現状と同じ高さが最も多いが、全体的には比較的 低い $1 \mathrm{~m} か ゙$ 最も多く、次いで $50 \mathrm{~cm}$ である。

3. 敷地の周囲に塀を巡らせる住戸が大半であるが、全体的には道路側 よりも隣家側や裏家側が多い。

4. 塀の高さも道路側が「目線高さ以上」が最も多く、また、隣家側や裏家 側に比べても高くなっている。理想の高さでも道路側が最も高く、かつ現 状と同じ高さが希望されることが多いが、全般的には現状より高さが低く なる傾向にある。

一方、道路側家面・隣家側・裏家側はいずれも現状より高いことが望ま れ、3者の比較では裹家側が最も高く、次いで隣家側、道路側家面とな る傾向が強い。

すなわち、道路側からの侵入を困難にすると共に、家側からの閉鎖感 を和らげ、䣃家側や裏家側に対しても閉鎖感の低減を図るためや隣人 への遠慮からか高さを抑える傾向が見られるが、理想は隣家や裹家を経 由しての侵入など防犯性をも考慮してか、さらに高くしたいと考えている。 5. 塀の種類は、道路側は多様であるが「竪格子・横栈」が多く、全体的 には視線透過性が高い。しかし、理想としては視線透過性を减じる方向 にある。隣家側・裏家側は「フェンス・ネット」が他に比べて非常に多い が、理想としてはよりハードな視線透過性の低い種類が好まれる。

6. 塀の高さや種類よりみると、視覚的には比較的開放的な庭が多いが、 現状よりは理想の方が閉鎖的になる。

7. プライバシー感は、どこから見られるにしても見られる程度が高いほど 気になる度合いが高い。道路側からの視線は最も気になり、隣家側や裹 家側ではどちらかというと裏家側の方が気になる。庭の中が見られるのに 比べて、家の中が見られることを極度に嫌がる傾向があり、家の中がちら ほら見えるのと庭の中がほとんど見えるのとでは、同程度の気にしかたと いえる。

どこからでも見えない方が気にする程度が低いものの、ほとんど見えな くても気にする層は存在する。また、道路から庭の中への視線について はプライバシー保護と防犯性との間に葛藤を示す者も多い。
8. 家の中への視線が気になるあまり、庭に面する空の開放性は低く、昼 間でもカーテンなどを通しての透明性の低い庭景観の享受となる傾向が 強い。

\begin{tabular}{|c|c|c|c|}
\hline 開口部の & \multicolumn{3}{|c|}{ 開口部の遮蔽 (主庭面) } \\
\hline & \multicolumn{2}{|c|}{ 装備遮蔽物 } & 亘間遮蔽物 \\
\hline & SA & MA & SA \\
\hline 厚手のカーテン & $16(6.0)$ & $180(67.2)$ & $6(2.7)$ \\
\hline 薄手のカーテン & $5(1.9)$ & $41(15.3)$ & $39(17.6)$ \\
\hline レースのカーテン & $13(4.9)$ & $193(72.0)$ & $118(53.2)$ \\
\hline すだれやよしず等 & $3(1.1)$ & $35(13.1)$ & $4(1.8)$ \\
\hline 雨 戸 & $6(2.2)$ & $162(60.4)$ & $6(2.7)$ \\
\hline 厚手のカーテン+レースのカーテン+雨户 & $87(32.5)$ & - & $4(1.8)$ \\
\hline 厚手のカーテン+レースのカーテン & $26(9.7)$ & 一 & $5(2.3)$ \\
\hline レースのカーテン+雨户 & $13(4.9)$ & - & $3(1.4)$ \\
\hline その他 & 27 種 99 & $38(14.2)$ & 16 種 37 \\
\hline 合 計 & & $268(100)$ & $222(100)$ \\
\hline 不 明 & & 10 & 55 \\
\hline
\end{tabular}

注記

注 1 :未調查住戸は、拒否ならびに留守宅である。

参考文献

1）住友むつみ、竹鴄祥夫:一戸建て住宅戸外空間の囲繞形態とプライバシー 感に関する研究、日本建築学会近畿支部研究報告集、計画系第 43 号、 pp. $69 \sim 72 、 2003.6$

2）住環境の計画編集委員会編: 住環境の計画2一住宅を計画する、彰国社、 pp. $34 \sim 35 、 1982$

3）梅津光男、坂本磐雄、藤田一枝:地方都市住居における庭の空間構成とそ の変容一青森県八戸市におけるケーススタディー、日本建築学会計画系論 文集、第535号、pp. 83 90、2000. 9

4）藤田一枝、梅津光男: 現代都市住居にお计庭の空間構成に関する研究 1. 庭の用途別部分スペースの面積構成について、日本建築学会学術講演 梗概集、E、pp. 107〜108、1993. 9

5）藤田一枝、梅津光男: 同上 2 . 主な庭の面積構成および住宅内部との関係 について、日本建筑学会学術講演梗概集、E、pp. 217 218、1994. 9

6) 藤田一枝、梅津光男: 同上 3 . 囲いの形態と機能について、日本建築学会 学術講演梗概集、E-2、pp. 199〜200、1995. 8

7）藤田一枝、梅津光男: 同上 4. 用途別部分スペースの配貫について、日本 建築学会学沅講演梗概集、E-2、pp. 243 244、1996. 9

8）藤田一枝、梅津光男:同上 5. 部分スペースのつくりの変化について、日本 建箱学会学術講演梗概集、E-2、pp. 133 134、1997.9

9）藤田一枝、梅津光男: 同上 6 . 庭の使い方と意識、日本建築学会学術講演 梗概集、E-2、pp. 243 244、1998. 9

10）相羽康郎、杉山岳巳:住宅地街路景観シミュレーションに関する研究ーその 4 住宅へのアプローチーについて、日本建築学会学術講演梗概集、 F-1、pp. 73 74、1997. 9

11）相羽康郎、杉山岳巳:同上一その5 家屋配置アルゴリズムへの改善につい て、日本建築学会学術講演梗概集、F-1、pp. 75 76、1997. 9

12）井上加奈子、仙田満、矢田努、井上寿:住宅地における「幈」の形態と住民 意識に関する研究一東京の6住宅地における調査より一、日本建築学会学 術講演梗概集、E-2、pp. 137〜 138、1999. 9

(2003年 6 月 4 日原稿受理，2003年11月14日採用決定) 